\title{
Sludge reduction potential of the activated sludge process by integrating an oligochaete reactor
}

\author{
Yuansong Wei*, Yawei Wang, Xuesong Guo, Junxin Liu \\ Research Center for Eco-Environmental Sciences, Chinese Academy of Sciences, P. O. Box 2871, Beijing 100085, PR China
}

\section{A R T I C L E I N F O}

\section{Article history:}

Received 2 May 2008

Received in revised form 15 June 2008

Accepted 16 June 2008

Available online 26 June 2008

\section{Keywords:}

Excess sludge

Oligochaete

Sludge reduction

Worm reactor

\begin{abstract}
A B S T R A C T
An oligochaete reactor linked to an integrated oxidation ditch with vertical cycle (IODVC) was used to investigate the sludge reduction potential induced by worms. The presence of Tubificidae was observed in the worm reactor throughout the operational period after its inoculation, and Tubificidae was occasionally found in the IODVC. Free-swimming worms, Aeolosoma hemprichi, Nais elinguis, and Aulophorus furcatus, were found in both the IODVC and the worm reactor, but $A$. hemprichi was dominant. A. hemprichi reached its maximum, 322 and 339 Aeolosoma/mL mixed liquor on day 49 in the worm reactor and the IODVC, respectively. The presence of oligochaetes or the integration of worm reactor with the IODVC had little effect on sludge yield, but the worm growth was helpful for improving sludge settling characteristics. The average sludge yield and sludge volume index (SVI) in the IODVC were $0.33 \mathrm{kgSS} / \mathrm{kgCOD}_{\text {removed }}$ and $78 \mathrm{~mL} / \mathrm{g}$, respectively. The worm presence had little impact on effluent quality of the IODVC, but it caused phosphorus release into the effluent. The average $\mathrm{COD}, \mathrm{NH}_{4}{ }^{+}-\mathrm{N}$, and SS concentrations in the effluent of the IODVC were $49.06,12.82$, and $58.25 \mathrm{mg} / \mathrm{L}$, respectively. No total nitrogen (TN) release into the effluent of the IODVC occurred.
\end{abstract}

(C) 2008 Elsevier B.V. All rights reserved.

\section{Introduction}

Excess sludge treatment and disposal represents a rising challenge for small and mid-scale municipal wastewater treatment plants (WWTPs) in China as a result of economic, environmental and regulation factors. Currently, different engineering strategies such as lysis-cryptic growth, uncoupling metabolism, maintenance metabolism, and predation on bacteria, are being developed for sludge reduction [1].

A way to enhance mineralization and reduce the sludge production is to exploit the organism in the process that predate on bacteria (sludge), by promoting their growth in an extra "grazing stage". During energy transfer from bacteria to higher trophic level organisms, energy is lost due to inefficient biomass conversion and thus the predator may make a large contribution to biomass reduction [2,3]. Recently, many studies have focused on sludge reduction induced by protozoa and metazoa grazing on bacteria [2-21]. It is well known that the presence of protozoa and metazoa in aerobic wastewater treatment processes plays an important role in keeping effluent clear by consuming dispersed bacteria and settled solids. Worms are the largest organisms observed during the microscopic investigation of activated sludge [22]. The perfor-

\footnotetext{
* Corresponding author. Tel.: +8610 62923543; fax: +86 1062849108 .

E-mail address: ys_wei@yahoo.com (Y. Wei).
}

mance of oligochaetes for sludge reduction in biological wastewater treatment has been paid more attention than that of protozoa for sludge reduction $[2,3,8-10,12,13,15-21]$. Different worms were found in these observations such as Nais elinguis, Pristina sp. and Aeolosoma hemprichi, but either Nais or Aeolosoma was predominant $[3,12,13,15,19]$. Although the presence of worms in the aerobic wastewater treatment may lead to substantial sludge reduction, the practical application of worms for sludge reduction is still uncontrollable in biological wastewater treatment processes because of unstable worm growth, e.g. alternative bloom and absence of worms, and high variation of worm density. In these mentioned researches $[2,3,8-10,12,13,15,19]$, worms grew together with bacteria in the same bioreactor. But bioreactors such as aeration tanks in activated sludge process were designed for bacterial growth rather than for worm growth. A suitable habitat may therefore be essential for stable growth and retention of worms. On the basis of worm presence in aerobic wastewater treatment processes, a novel worm reactor was developed to enhance worm growth in order to improve sludge reduction. This worm reactor can be used to treat discharged excess sludge from the activated sludge process [16,17], or be integrated into the activated sludge process through treating returned sludge. In this study, a down flow type of worm reactor consisted of two sections, one for free-swimming worms and another for sessile worms, and was combined with an integrated oxidation ditch with vertical cycle (IODVC) [23] to form a loop. In this loop, the discharged excess sludge from the IODVC was firstly 


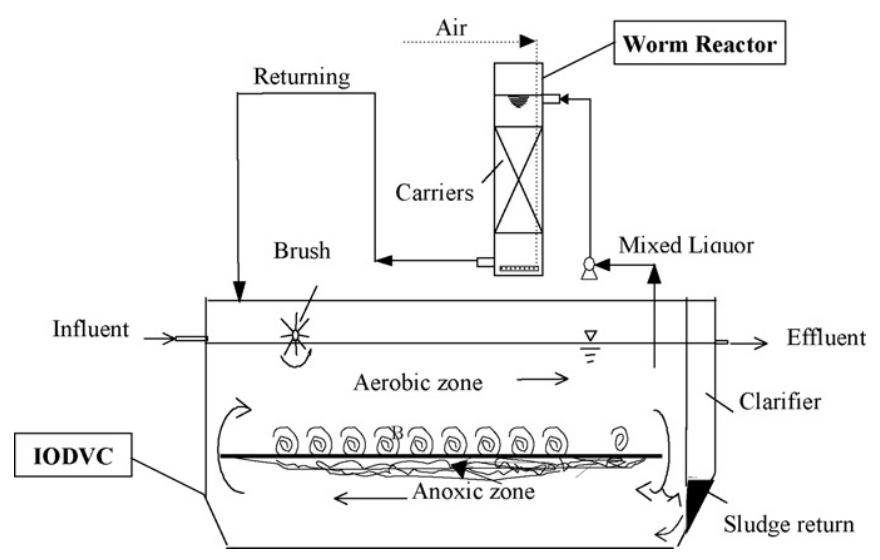

Fig. 1. Diagram of the loop formed between the integrated oxidation ditch with vertical cycle (IODVC) and the worm reactor.

treated by the worm reactor and then returned to the channel of the IODVC. Therefore the purpose of this study was to check sludge reduction potential in the IODVC integrated with this new worm reactor developed to enhance worm growth for sludge reduction. Meanwhile, the impact of worm growth on the IODVC wastewater treatment was also investigated.

\section{Materials and methods}

\subsection{Experiment facility}

Fig. 1 shows the diagram of the worm reactor treating discharged excess sludge from the IODVC. The single channel of the IODVC is divided into two ditches by a plate: a top one and a bottom one. Different from the horizontal circle of the conventional oxidation ditch, the flow of the IODVC recycles from the top to the bottom in the vertical circle as the brush is running. As a result, the different zones, aerobic in the top and anoxic/anaerobic in the bottom, are formed. In the IODVC, the clarifier, set at the opposite end of brush in the ditch, does not affect the hydrodynamic characteristics of the mixed liquid in the ditch and the sludge can automatically return to the down ditch without any pump [23]. In this study, both the IODVC and the worm reactor were made of Lucite so that the experiment was easily observed, and their working volumes were 33.0 and $2.60 \mathrm{~L}$, respectively. The laboratory-scale IODVC consists of a single-channel, a Kesner type brush, and an integral clarifier. The down flow type of worm reactor had two sections, one section for free-swimming worms, another section for sessile worms filled with slags. The porosity and size of slags were about $80 \%$ and $2 \mathrm{~cm}$, respectively.

\subsection{Operating conditions}

During 90 days of experimental period, this worm reactor was continuously fed with the mixed liquor from the channel of the IODVC using a peristaltic pump (Longer BT00-100M, China), and the processed sludge from the worm reactor was then returned to the channel of the IODVC. Therefore the fed sludge concentration of the worm reactor was the same as that in the channel of the IODVC. No sludge wasting was carried out from the channel of the IODVC except for $2 \mathrm{~L}$ sludge wasted on day 3, day 31 and day 58 , respectively, and no sludge from the worm reactor was discharged throughout the operation period. The worm reactor was alternatively aerated by two air compressors controlled by a timer. The municipal wastewater (Table 1 ) was continuously fed into the IODVC using a peristaltic pump (BT00-300M, China) throughout the
Table 1

Operation conditions and the fed municipal wastewater characteristics in the integrated oxidation ditch with vertical cycle (IODVC) throughout the operational period

Operation conditions (average \pm S.D.) $\quad$ Fed municipal wastewater (average \pm S.D.)

$T\left({ }^{\circ} \mathrm{C}\right): 21.18 \pm 2.91 \quad \operatorname{COD}(\mathrm{mg} / \mathrm{L}): 311.25 \pm 98.80$

$\mathrm{pH}: 6.06 \pm 0.54$

DO $(\mathrm{mg} / \mathrm{L}): 4.63 \pm 0.98$

HRT $(h): 33.63 \pm 8.92$

F/M (kgCOD/kgVSS d): $0.23 \pm 0.15$

Recycle ratio: $1.32 \pm 0.45^{\text {a }}$

TSS $(\mathrm{g} / \mathrm{L}): 1.59 \pm 0.38$

$\operatorname{VSS}(\mathrm{g} / \mathrm{L}): 1.25 \pm 0.30$

$\mathrm{SS}(\mathrm{mg} / \mathrm{L}): 130 \pm 98$

$\mathrm{TN}(\mathrm{mg} / \mathrm{L}): 77.60 \pm 5.47$

$\mathrm{NH}_{4}{ }^{+}-\mathrm{N}(\mathrm{mg} / \mathrm{L}): 72.76 \pm 17.17$

$\mathrm{NO}_{3}{ }^{-}-\mathrm{N}(\mathrm{mg} / \mathrm{L}): 0.05 \pm 0.17$

$\mathrm{NO}_{2}{ }^{-}-\mathrm{N}(\mathrm{mg} / \mathrm{L}): 0.13 \pm 0.23$

$\mathrm{TP}(\mathrm{mg} / \mathrm{L}): 7.59 \pm 1.85$

Ratio of VSS/TSS: $0.74 \pm 0.08$

a Recycle ratio is the ratio of the input sludge flow of the worm reactor to the influent flow of the IODVC.

operational period. In this study, $200 \mathrm{~mL}$ of Tubificidae mainly consisted of Limnodrilus hoffmeisteri from a local fish-shop were used to initially inoculate in the worm reactor running in the steady state. The dissolved oxygen (DO) concentration (YSI 52CE, USA), pH (PHS3C, China) and temperature in the IODVC were monitored daily. The average $\mathrm{pH}$ value in the IODVC was stable at 6.06, and the average DO concentration in the IODVC was kept at or above $2.0 \mathrm{mg} / \mathrm{L}$ by adjusting speed of the Kesner type brush (Table 1 ). The average hydraulic retention times (HRT) in both the IODVC and the worm reactor were 33.63 and $2.18 \mathrm{~h}$, respectively.

\subsection{Analysis}

Sludge samples were regularly taken from both the IODVC and the worm reactor in the morning. All concentrations of chemical oxygen demand (COD), $\mathrm{NO}_{2}{ }^{-}-\mathrm{N}, \mathrm{NO}_{3}{ }^{-}-\mathrm{N}$ and $\mathrm{PO}_{4}{ }^{3-}-\mathrm{P}$ were measured from the supernatant of samples in influent and effluent of both reactors. The concentrations of COD were determined with a COD analyzer (HATO ${ }^{\circledR}$ CTL-12, China). The concentrations of $\mathrm{NO}_{2}{ }^{-}-\mathrm{N}, \mathrm{NO}_{3}{ }^{-}-\mathrm{N}$ and $\mathrm{PO}_{4}{ }^{3-}-\mathrm{P}$ were determined in the filtrate of a $0.45 \mu \mathrm{m}$ membrane filter by a $4500 \mathrm{i}$ Ion Chromatograph (Dionex Corp., USA). Total suspended solids (TSS) and volatile suspended solids (VSS) were determined after drying at $104^{\circ} \mathrm{C}(4 \mathrm{~h})$ and $600^{\circ} \mathrm{C}$ $(2 \mathrm{~h})$, respectively. The amounts of free-swimming worms such as A. hemprichi were counted from a $1 \mathrm{~mL}$ sludge sample by a stereo microscope (Motic K-400, China). However, Tubificidae in the worm reactor was not counted because of difficulty taking sample of Tubificidae attached on the carriers or stayed on the bottom of the worm reactor. Therefore, quantitative sampling of Tubificidae was not possible. The values of free-swimming worms were the average of triplicate samples. The sludge yield of the IODVC in a given period between the $n+i$ day and the $n$ day was calculated based on the following equations:

$$
\begin{aligned}
\Delta \mathrm{TSS}= & \mathrm{TSS}_{n+i}-\mathrm{TSS}_{n}+\mathrm{TSS}_{\mathrm{w}} \\
= & 10^{-3}\left[\left(Q_{\text {in }} \mathrm{SS}_{\text {in }}+V_{\mathrm{a}} X_{\mathrm{a}}+V_{\mathrm{c}} X_{\mathrm{r}}+V_{\text {worm }} X_{\text {worm }}\right)_{n+i}\right. \\
& \left.-\left(Q_{\text {in }} \mathrm{SS}_{\text {out }}+V_{\mathrm{a}} X_{\mathrm{a}}+V_{\mathrm{c}} X_{\mathrm{r}}+V_{\text {worm }} X_{\text {worm }}\right)_{n}+i Q_{\mathrm{w}} X_{\mathrm{r}}\right]
\end{aligned}
$$

$$
\begin{aligned}
\Delta \operatorname{COD}_{\text {removed }} & =\left(\operatorname{COD}_{\text {removed }}\right)_{n+i}-\left(\operatorname{COD}_{\text {removed }}\right)_{n} \\
& =10^{-6} \times 24 \times i \sum_{n}^{n+i} \mathrm{Q}_{\text {in }}\left(\sum_{n}^{n+i} \operatorname{COD}_{\text {in }}-\sum_{n}^{n+i} \operatorname{COD}_{\text {out }}\right)
\end{aligned}
$$

$Y=\frac{\Delta \mathrm{TSS}}{\Delta \mathrm{COD}_{\text {removed }}}$ 
where $Y$ is the sludge yield in the IODVC during $i$ days, $\mathrm{kg} \mathrm{SS} / \mathrm{kg}$ $\mathrm{COD}_{\text {removed }}, \triangle \mathrm{TSS}$ is the amount of sludge produced in the IODVC during $i$ days, $\mathrm{kg} \mathrm{SS} ; \triangle \mathrm{COD}_{\text {removed }}$ is the amount of COD removed in the IODVC during $i$ days, $\mathrm{kg} \mathrm{COD}_{\text {removed }}, Q_{\text {in }}$ is the influent flow of the IODVC, $\mathrm{L} / \mathrm{h}, \mathrm{Q}_{\mathrm{w}}$ is the flow of wasting sludge from the IODVC, $\mathrm{L} / \mathrm{d}$, $\mathrm{SS}_{\text {in }}, \mathrm{SS}_{\text {out }}$ is the suspended solids (SS) concentrations of influent and effluent, g/L, respectively, $\mathrm{TSS}_{n}, \mathrm{TSS}_{n+i}, \mathrm{TSS}_{\mathrm{w}}$ are the amounts of sludge in both the IODVC and the worm reactor on day $n$ and day $n+i$, the amounts of sludge wasted from the IODVC during $i$ days, respectively, $V_{\mathrm{a}}, V_{\mathrm{c}}, V_{\text {worm }}$ are the volumes of chanel and clarifier of the IODVC, and volume of the section for free-swimming worms in the worm reactor, $\mathrm{L}$, respectively, $X_{\mathrm{a}}, X_{\mathrm{r}}, X_{\text {worm }}$ are the total suspended solids (TSS) concentrations in the channel and the returned sludge of the IODVC, and TSS concentration of the section for free-swimming worms in the worm reactor, g/L, respectively, $\mathrm{COD}_{\text {in }}, \mathrm{COD}_{\text {out }}$ are the COD concentrations of influent and effluent in the IODVC, $\mathrm{mg} / \mathrm{L}$, respectively, 24 is the time transfer factor and $10^{-3}, 10^{-6}$ are the mass transfer factor.

\section{Results and discussion}

\subsection{Worm growth}

Aggregations of Tubificidae were visible, and appeared to increase on the carriers and on the bottom of the worm reactor several days after the worm inoculation. The presence of Tubificidae was observed in the worm reactor throughout the operational period, but Tubificidae were occasionally found in the IODVC. Free-swimming worms, including A. hemprichi, $N$. elinguis, and Aulophorus furcatus, were found in both the IODVC and the worm reactor, but $A$. hemprichi were dominant in these two reactors, $N$. elinguis and $A$. furcatus occasionally occurred. Both the amounts of free-swimming worm and the free-swimming worm density in the IODVC were higher than those in the worm reactor from day 3 to day 72. The amounts of $A$. hemprichi initially increased, then reached to its maximum of $339 \mathrm{no} . / \mathrm{mL}$ in the IODVC and $322 \mathrm{no} . / \mathrm{mL}$ in the worm reactor on day 49 , respectively, but finally disappeared in both reactors on day 87 (Fig. 2). The average free-swimming worm densities in both the IODVC and the worm reactor were $72 \pm 76$ and $82 \pm 99$ no./mgVSS, respectively, and their maximal worm densities occurred on day 58 reaching 211 and 309 no./mgVSS, respectively. The size of $A$. hemprichi was among $0.5-2 \mathrm{~mm}$, the same as results of literatures $[12,15,19]$. Compared with previous researches in membrane bioreactor and conventional activated sludge process $[12,15,19]$, the amounts of free-swimming worms in this study as shown in Table 2 were lower than their results, but the free-

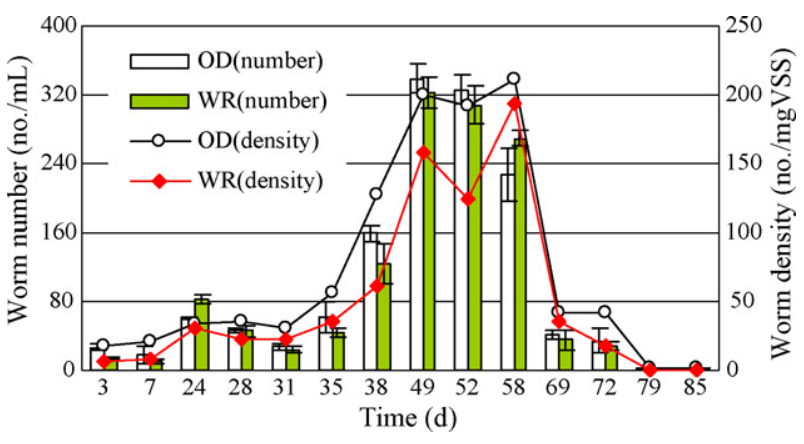

Fig. 2. Profiles of free-swimming worms in the integrated oxidation ditch with vertical cycle (IODVC) and the worm reactor (OD, oxidation ditch; WR, worm reactor).

swimming worm densities, including average and maximal values, were higher than their results.

Metazoa like Tubificidae occur less in aerobic wastewater treatment processes due to the lack of suitable niches for growth, and introduction of carrier material inside the system may thus improve the growth condition for these metazoa [9]. These results of this study not only confirmed this above-mentioned concept, but also showed that application of the worm reactor was helpful for long-term retention of sessile worms. However, sudden occurrence and disappearance of free-swimming worms in this study was the same as the results reported in literature $[12,15,19]$. The impacts of process conditions on worm growth in both membrane bioreactor (MBR) and conventional activated sludge process (CAS) were investigated, including eight operation parameters (TSS, HRT, SRT, F/M, recycle ratio, temperature, $\mathrm{pH}$, and DO), statistics analysis showed that only $\mathrm{F} / \mathrm{M}$ had no impact on worm growth in the MBR, and SRT was the only parameter that did not affect worm growth in the CAS reactor [15]. However, it is still little known why free-swimming worms suddenly bloom and disappearance in activated sludge processes, which needs further research in the future.

\subsection{Sludge yield and sludge settling characteristics}

As shown in Table 2, the average TSS and VSS concentrations in the IODVC were $1.59 \pm 0.38$ and $1.25 \pm 0.30 \mathrm{~g} / \mathrm{L}$, respectively. The ratio of TSS and VSS in the IODVC was $0.74 \pm 0.08$, showing little inert solids accumulated in biomass. The average concentrations of SS in the influent and the effluent of the IODVC were $130 \pm 98$ and $53 \pm 53 \mathrm{mg} / \mathrm{L}$, respectively, which means no sludge loss in effluent

Table 2

Comparison of sludge reduction induced by predation of oligochaetes in literature data and this study

\begin{tabular}{|c|c|c|c|c|c|}
\hline Operation conditions & $\begin{array}{l}\text { Dominant } \\
\text { oligochaete }\end{array}$ & Total worms ${ }^{\mathrm{a}}$ (no./mL mixed liquor) & $\begin{array}{l}\text { Worm density }{ }^{\text {a }} \text { (total } \\
\text { worms/mgVSS) }\end{array}$ & $\begin{array}{l}\text { Sludge yield } \\
\left(\mathrm{kgSS} / \mathrm{kgCOD}_{\text {removed }}\right)\end{array}$ & Reference \\
\hline $\begin{array}{l}\text { Pilot activated sludge system; } 18-23^{\circ} \mathrm{C} \text {; } \\
\text { domestic wastewater }\end{array}$ & Tubificidae & - & - & 0.15 & {$[8-10]$} \\
\hline $\begin{array}{l}\text { Pilot oxidation ditch; } 18-23^{\circ} \mathrm{C} \text {; } \\
\text { domestic wastewater }\end{array}$ & Tubificidae & - & - & 0.17 & {$[8-10]$} \\
\hline $\begin{array}{l}\text { Pilot suction submerged MBR; } 20^{\circ} \mathrm{C} \text {; } \\
\text { municipal wastewater }\end{array}$ & Aeolosoma hemprichi & Maximum: 693 & - & $0.00-0.12$ & {$[12]$} \\
\hline $\begin{array}{l}\text { Pilot gravitational submerged MBR; } \\
20^{\circ} \mathrm{C} \text {; municipal wastewater }\end{array}$ & Aeolosoma hemprichi & Maximum: 3842 & - & $0.10-0.15$ & {$[12]$} \\
\hline $\begin{array}{l}\text { Pilot activated sludge system; } 20^{\circ} \mathrm{C} \text {; } \\
\text { domestic wastewater }\end{array}$ & $\begin{array}{l}\text { Aeolosoma hemprichi, } \\
\text { Nais elinguis }\end{array}$ & Maximum:2599; average: 374 & $\begin{array}{l}\text { Maximum: } 302 \text {; } \\
\text { average: } 72\end{array}$ & 0.17 & {$[15]$} \\
\hline $\begin{array}{l}\text { Bench activated sludge system; } \\
20-25^{\circ} \mathrm{C} \text {; synthetic wastewater }\end{array}$ & Aeolosoma hemprichi & Maximum: 290 & Maximum: 115 & $0.53-6.32^{\mathrm{b}}$ & [19] \\
\hline $\begin{array}{l}\text { Bench activated sludge system; } \\
17-25^{\circ} \mathrm{C} \text {; domestic wastewater }\end{array}$ & Aeolosoma hemprichi & Maximum: 339; average: 98 & $\begin{array}{l}\text { Maximum: } 309 \\
\text { average: } 82\end{array}$ & 0.33 & This study \\
\hline
\end{tabular}

a Data based on Aeolosoma hemprichi.

b Unit is $\mathrm{mg}$ VSS/mg A. hemprichi $\times \mathrm{d}$. 


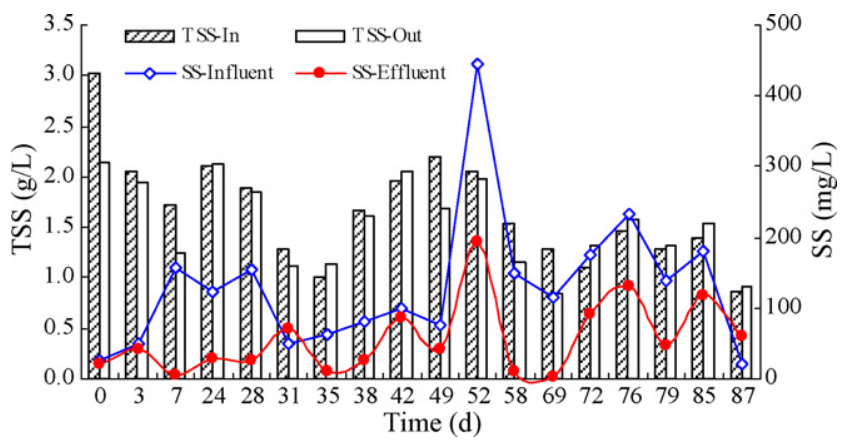

Fig. 3. Profiles of TSS-in and TSS-out concentrations in the worm reactor and SS concentrations of influent and effluent in the integrated oxidation ditch with vertical cycle (IODVC)

occurred during the operation period of the IODVC. The average concentrations of TSS in the fed sludge and the returned sludge of the worm reactor were $1.59 \pm 0.38$ and $1.51 \pm 0.38 \mathrm{~g} / \mathrm{L}$, respectively ( shown in Fig. 3). No sludge accumulation was observed in the worm reactor. Fig. 4 shows changes of sludge yield and worm density in the IODVC. The average sludge yield in the IODVC throughout the operational period was $0.33 \pm 0.20 \mathrm{kgSS} / \mathrm{kgCOD}$ removed, much higher than those sludge yields $(0.00-0.17 \mathrm{kgSS} / \mathrm{kgCOD}$ removed $)$ in their researches $[8-10,12,15]$. Without linking worm reactor, the average sludge yield of the IODVC was $0.25 \mathrm{kgSS} / \mathrm{kgCOD}$ removed [24]. Statistical analysis did not show any significant correlation between the presence of worms and the sludge yield in the IODVC. These results suggested that the presence of oligochaetes or the integration of worm reactor with the IODVC had little effect on sludge yield. Lumxy et al. [25] found that the presence or absence of the metazoa population did not have any significant effect on the increasing pattern of MLSS, i.e. metazoa population about $1000-2000$ per $\mathrm{mL}$ was not effective to reduce sludge production in the accumulation phase in MBR. Results of batch tests also showed that Aeolosomatidae was proved to have a more significant effect on reducing sludge volume than on reducing sludge biomass within 3 days [26]. Hence further research will be needed to evaluate the capacity of oligochaetes on sludge biomass reduction and sludge volume reduction in the future.

As shown in Fig. 5A, the sludge volume index (SVI) gradually decreased during initial 42 days and then stabilized since day 52. The average SVI of activated sludge in the IODVC were $78 \pm 32 \mathrm{~mL} / \mathrm{g}$, and that of returned sludge from the worm reactor was $80 \pm 31 \mathrm{~mL} / \mathrm{g}$. Fig. 5B clearly shows that the worm growth significantly affected the SVI in the IODVC during day 3-58. These results showed that the worms' presence was helpful for improving sludge settling characteristics, the same as their results $[12,13,15,19-21]$.

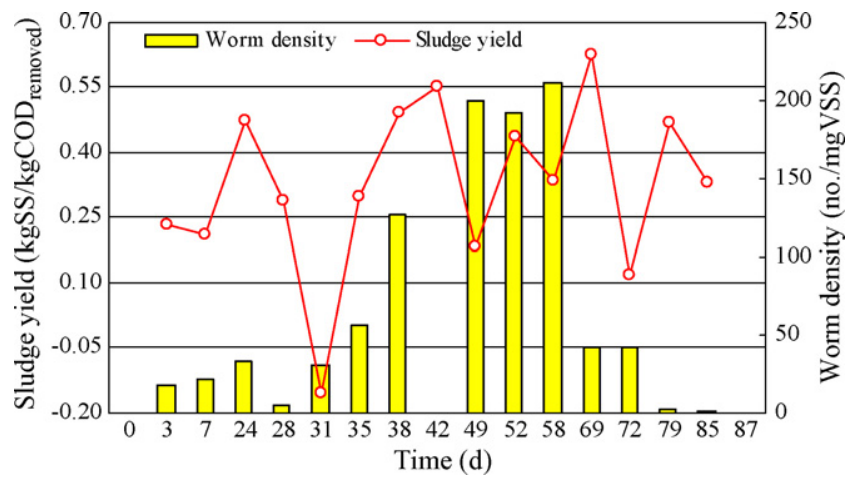

Fig. 4. Profiles of sludge yield and free-swimming worm density in the integrated oxidation ditch with vertical cycle (IODVC).
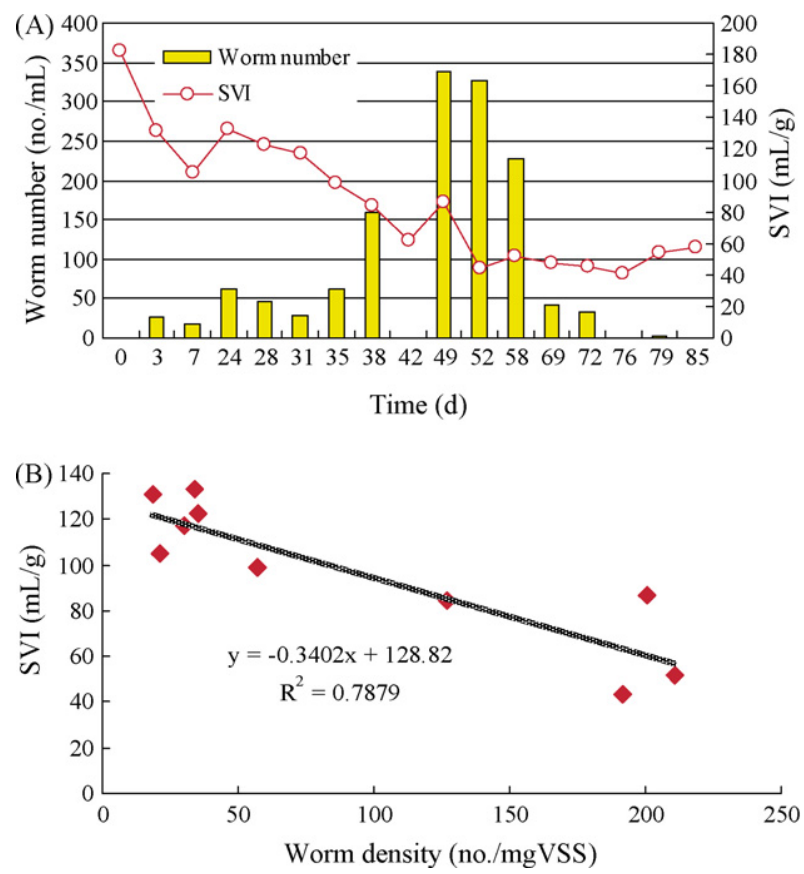

Fig. 5. Profiles of free-swimming worm density and SVI in the integrated oxidation ditch with vertical cycle (IODVC): (A) free-swimming worm number and SVI and (B) relationship of free-swimming worm density and SVI during day 3-58.

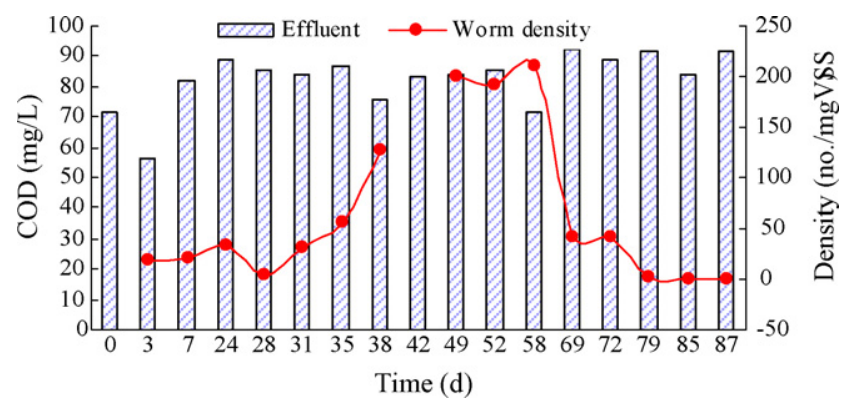

Fig. 6. Profiles of effluent COD and free-swimming worm density in the integrated oxidation ditch with vertical cycle (IODVC).

\subsection{COD and nutrients removals in the IODVC}

The average COD in the effluent and COD removal rate of the IODVC were $49.06 \pm 16.14 \mathrm{mg} / \mathrm{L}$ and $82.52 \pm 9.27 \%$, respectively. As shown in Fig. 6, the free-swimming worm presence and absence in the IODVC had little impact on effluent COD during the operational period. The average $\mathrm{NH}_{4}{ }^{+}-\mathrm{N}$, TN, TP concentrations in the effluent of the IODVC were $12.82 \pm 12.87,71.10 \pm 14.89$ and $8.05 \pm 1.73 \mathrm{mg} / \mathrm{L}$, respectively (Table 3 ), and the average $\mathrm{NH}_{4}{ }^{+}-\mathrm{N}$ removal rate of

Table 3

COD and nutrients removals in both the integrated oxidation ditch with vertical cycle (IODVC) and the worm reactor throughout the operational period

\begin{tabular}{lccccc}
\hline Parameter & \multicolumn{2}{l}{ IODVC (average \pm S.D. } & & \multicolumn{2}{l}{ Worm reactor (average \pm S.D.) } \\
\cline { 2 - 3 } & In $(\mathrm{mg} / \mathrm{L})$ & Out $(\mathrm{mg} / \mathrm{L})$ & & In $(\mathrm{mg} / \mathrm{L})$ & Out $(\mathrm{mg} / \mathrm{L})$ \\
\hline $\mathrm{COD}$ & $311.25 \pm 98.80$ & $49.06 \pm 16.14$ & & $48.26 \pm 17.41$ & $39.28 \pm 15.49$ \\
$\mathrm{TN}$ & $77.60 \pm 5.47$ & $71.10 \pm 14.89$ & & $73.04 \pm 15.80$ & $71.95 \pm 12.41$ \\
$\mathrm{NH}_{4}{ }^{+}-\mathrm{N}$ & $72.76 \pm 17.17$ & $12.82 \pm 12.57$ & & $12.08 \pm 12.25$ & $6.82 \pm 9.53$ \\
$\mathrm{NO}_{3}{ }^{-}-\mathrm{N}$ & $0.05 \pm 0.17$ & $54.58 \pm 25.27$ & & $54.93 \pm 24.81$ & $57.93 \pm 22.97$ \\
$\mathrm{NO}_{2}{ }^{-}-\mathrm{N}$ & $0.13 \pm 0.23$ & $0.16 \pm 0.28$ & & $0.12 \pm 0.15$ & $0.08 \pm 0.11$ \\
$\mathrm{TP}$ & $7.59 \pm 1.85$ & $8.05 \pm 1.73$ & & $8.10 \pm 2.15$ & $7.42 \pm 2.01$ \\
$\mathrm{PO}_{4}{ }^{3-}-\mathrm{P}$ & $7.38 \pm 2.36$ & $8.04 \pm 2.25$ & & $8.05 \pm 2.64$ & $7.41 \pm 2.40$ \\
\hline
\end{tabular}


the IODVC was $83.64 \pm 14.63 \%$. Compared to effluent quality of the IODVC treating domestic wastewater without the worm reactor $[21,22]$, the effluent quality (e.g. COD, SS and $\mathrm{NH}_{4}{ }^{+}-\mathrm{N}$ ) of the IODVC in this study was a little worse. Possible explanations were (i) that the predation on bacteria by worms may cause the increase of SS in the effluent, and thus result in higher COD and SS in the effluent; (ii) that the lower $\mathrm{C} / \mathrm{N}$ ratio of the fed wastewater in this study compared to that in their research [21,22], as well as lack of alkalinity, may lead to lower ammonia nitrogen removal rate. Although TN in the effluent was lower than that in the influent of the IODVC, it is noted that both TP and $\mathrm{PO}_{4}{ }^{3-}-\mathrm{P}$ concentrations were a little higher in the effluent than in the influent (Table 3 ). This result showed that phosphorus release into the effluent occurred in the IODVC, the same as those results reported in literature $[8-10,15]$. However, such phenomenon of phosphorus increase of effluent did not happen in the worm reactor.

\section{Conclusions}

The performance of sludge reduction in the IODVC by integrating an oligochaete reactor was investigated, and conclusions were made as follows:

(1) The presence of Tubificidae was observed in the worm reactor throughout the operation period after its inoculation, but Tubificidae was occasionally found in the IODVC. Free-swimming worms, A. hemprichi, N. elinguis, and A. furcatus, were found in both the IODVC and the worm reactor, Aeolosoma was dominant, however

(2) The presence of oligochaetes or the integration of worm reactor with the IODVC had little effect on sludge yield. The average sludge yield in the IODVC was $0.33 \mathrm{kgSS} / \mathrm{kgCOD}$ removed However, the worm growth was helpful for improving sludge settling characteristics, and the average SVI of activated sludge in the IODVC were $78 \mathrm{~mL} / \mathrm{g}$.

(3) Application of the worm reactor was helpful for long-term retention of sessile worms in activated sludge process. However, it is still little known why free-swimming worms suddenly bloom and disappearance in activated sludge processes, which needs further research.

(4) The average COD, $\mathrm{NH}_{4}{ }^{+}-\mathrm{N}$, and SS concentrations in the effluent of the IODVC were $49.06,12.82$, and $58.25 \mathrm{mg} / \mathrm{L}$, respectively. The presence and absence of free-swimming worms in the IODVC had little impact on COD removal during the operational period. No TN release into the effluent of the IODVC occurred, but the phosphorus release into the effluent of the IODVC was observed.

\section{Acknowledgements}

This work is financially supported by the National Natural Science Foundation of China (50408021) and the National Hi-Tech Development Program (863 Program) of China (2007AA06Z347).

\section{References}

[1] Y.S. Wei, R.T. Van Houten, A.R. Borger, D.H. Eikelboom, Y.B. Fan, Minimization of excess sludge production for biological wastewater treatment, Water Res. 37 (2003) 4453-4467.

[2] C.H. Ratsak, S.A.L.M. Kooijman, B.W. Kooi, Modelling the growth of an oligochaete on activated sludge, Water Res. 27 (1993) 739-747.

[3] C.H. Ratsak, Grazer induced sludge reduction in wastewater treatment, Ph.D. Thesis, Vrije University, The Netherlands, 1994.

[4] T. Welander N.M. Lee, Minimization of sludge production in aerobic treatment by use of predators, in: The Second International Symposium on Environmental Biotechnology, Brighton, UK, July 1994, pp. 4-6.

[5] N.M. Lee, T. Welander, Influence of predator in nitrification in aerobic biofilm, Water Sci. Technol. 29-7 (1994) 355-363.

[6] N.M. Lee, T. Welander, Reducing sludge production in aerobic wastewater treatment through manipulation of the ecosystem, Water Res. 30 (1996) 1781 1790.

[7] N.M. Lee, T. Welander, Use of protozoa and metazoa for decreasing sludge production in aerobic wastewater treatment, Biotechnol. Lett. 18 (1996) 429434.

[8] J.H. Rensink, R. Corstanje, J.H. van der Pal, A new approach to sludge reduction by metazoa, in: 10th European Sewage and Reuse Symposium, IFAT, Munchen, 1996, pp. 339-364.

[9] J.H. Rensink, W.H. Rulkens, Using metazoa to reduce sludge production, Water Sci. Technol. 36-11 (1997) 171-179.

[10] P.M.J. Janssen, W.H. Rulkens, J.H. Rensink, H.F. van der Poest, The potential for metazoa in biological wastewater treatment, Water Qual. Int. (WQI) (September/October) (1998) 25-27.

[11] W. Ghyoot, W. Verstraete, Reduced sludge production in a two-stage membrane-assisted bioreactor, Water Res. 34 (2000) 205-215

[12] S.Y. Zhang, Polluted water treatment by the combining processes of membrane separation and biodegradation, Ph.D. Thesis, Research Centre for Eco-Environmental Sciences, Chinese Academy of Sciences, China, 2000.

[13] C.H. Ratsak, Effects of Nais elinguis on the performance of an activated sludge plant, Hydrobiologia 463 (2001) 217-222.

[14] J. Lapinski, A. Tunnacliffe, Reduction of suspended biomass in municipal wastewater using bdelloid rotifers, Water Res. 37 (2003) 2027-2034.

[15] Y.S. Wei, R.T. Van Houten, A.R. Borger, D.H. Eikelboom, Y.B. Fan, Comparison performances of membrane bioreactor (MBR) and conventional activated sludge (CAS) processes on sludge reduction induced by Oligochaete, Environ. Sci. Technol. 37 (2003) 3171-3180.

[16] Y.S. Wei, J.X. Liu, The discharged excess sludge treated by oligochaeta, Water Sci. Technol. 52-10/11 (2005) 265-272.

[17] Y.S. Wei, J.X. Liu, Sludge reduction with a novel combined worm-reactor, Hydrobiologia 564 (2006) 213-222.

[18] P. Liang, X. Huang, Y. Qian, Y.S. Wei, G.J. Ding, Determination and comparison of sludge reduction rates caused by microfaunas' predation, Bioresour. Technol. 97 (2006) 854-861.

[19] P. Liang, X. Huang, Y. Qian, Excess sludge reduction in activated sludge process through predation of Aeolosoma hemprichi, Biochem. Eng. J. 28 (2006) 117122.

[20] X. Huang, P. Liang, Y. Qian, Excess sludge reduction induced by Tubifex tubifex in a recycled sludge reactor, J. Biotechnol. 127 (2007) 443-451.

[21] H.J.H. Elissen, T.L.G. Hendrickx, H. Temmink, C.J.N. Buisman, A new reactor concept for sludge reduction using aquatic worms, Water Res. 40 (2006) 3713-3718.

[22] D.H. Eikelboom, Process Control of Activated Sludge Plants by Microscopic Investigation, IWA Publishing, UK, 2000, pp. 85-102.

[23] S.B. Xia, J.X. Liu, An innovative integrated oxidation ditch with vertical circle for domestic wastewater treatment, Process Biochem. 39 (2004) 11111117.

[24] S.B. Xia, An innovative integrated oxidation ditch with vertical circle (IODVC) for wastewater treatment, Ph.D. Thesis, Research Centre for Eco-Environmental Sciences, Chinese Academy of Sciences, China, 2003.

[25] B.S. Lumxy, T. Kubo, K. Yamamoto, Sludge reduction potential of metozoa in membrane bioreactors, Water Sci. Technol. 44 (10) (2001) 197-202.

[26] R. Falconi, E. Cristiani, G. Tomba, et al., Sludge reduction induced by two species of Aeolosomatidae, in: The 10th International Symposium on Aquatic Oligochaeta, Wuhan, China, October 2006, pp. 16-21. 